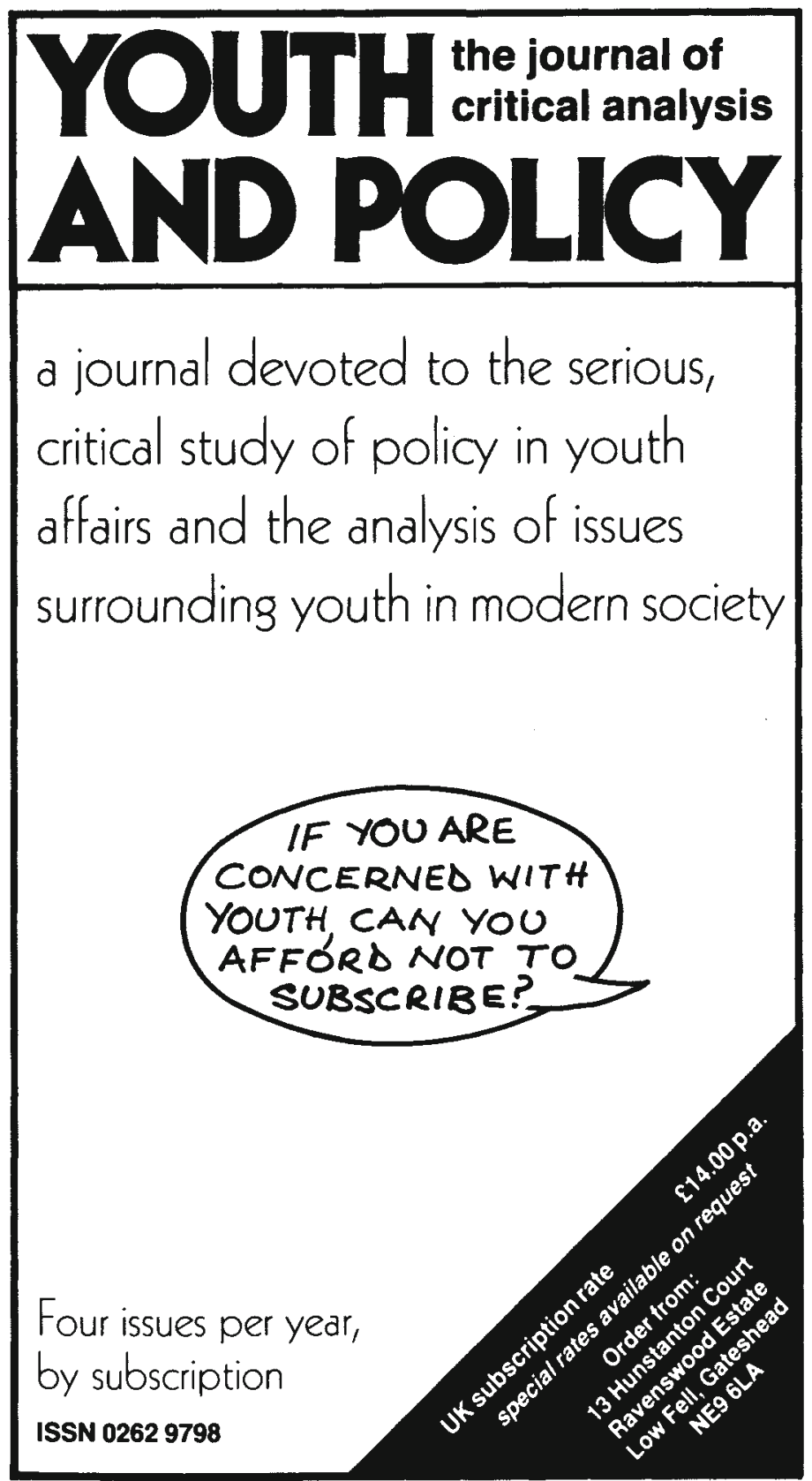


Gender and Generation 


\section{YOUTH QUESTIONS}

\section{Series Editors: PHILIP COHEN and ANGELA McROBBIE}

This series sets out to question the ways in which youth has traditionally been defined by social scientists and policy-makers, by the caring professions and the mass media, as well as in 'common-sense' ideology. It explores some of the new directions in research and practice which are beginning to challenge existing patterns of knowledge and provision. Each book examines a particular aspect of the youth question in depth. All of them seek to connect their concerns to the major political and intellectual debates that are now taking place around the present crisis and future shape of our society. The series will be of interest to those who deal professionally with young people, especially those concerned with the development of socialist, feminist and anti-racist perspectives. But it is also aimed at students and general readers who want a lively and accessible introduction to some of the most awkward but important issues of our time.

PUBLISHED

Inge Bates, John Clarke, Philip Cohen, Dan Finn, Robert Moore and Paul Willis Schooling for the Dole?

The New Vocationalism

Cynthia Cockburn

Two-Track Training

Sex Inequalities and the YTS

Philip Cohen and Harwant Bains (eds)

Multi-Racist Britain

Andrew Dewdney and Martin Lister Youth, Culture and Photography

Dan Finn

Training without Jobs: New Deaks and Broken Promises

Angela McRobbie and Mica Nava (eds)

Gender and Generation

Angela McRobbie (ed)

Zoot Suits and Second Hand

Dresses:

An Anthology of Fashion and Music

Kevin Robins and Frank Webster

The Technical Fix

\section{FORTHCOMING}

Desmond Bell

Acts of Union

Youth Culture and Sectarianism

in Northern Ireland

Philip Cohen and Graham

Murdock (eds)

The Making of the Youth

Question

Robert G. Hollands

The Long Transition

Class, Culture and Youth Training

Angela McRobbie

Feminism and Youth Culture 


\title{
Gender and Generation
}

\author{
Edited by \\ Angela McRobbie and Mica Nava
}

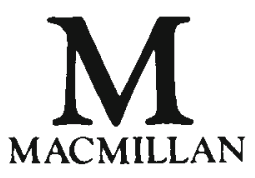


(C) Erica Carter, Adrian Chappell, Barbara Hudson, Angela McRobbie, Mica Nava, Valerie Walkerdine, Julian Wood 1984

All rights reserved. No reproduction, copy or transmission of this publication may be made without written permission.

No paragraph of this publication may be reproduced, copied or transmitted save with written permission or in accordance with the provisions of the Copyright, Designs and Patents Act 1988, or under the terms of any licence permitting limited copying issued by the Copyright Licensing Agency, 33-4 Alfred Place, London WC1E 7DP.

Any person who does any unauthorised act in relation to this publication may be liable to criminal prosecution and civil claims for damages.

First published 1984 by MACMILLAN EDUCATION LTD

Houndmills, Basingstoke, Hampshire RG21 2XS

and London

Companies and representatives

throughout the world

ISBN 978-0-333-33252-8 ISBN 978-1-349-17661-8 (eBook)

DOI 10.1007/978-1-349-17661-8

A catalogue record for this book is available from the British Library.

Reprinted 1987, 1991 


\section{Contents}

Acknowledgements vii

Contributors viii

Introduction $\quad$ ix

1 Youth Service Provision, Social Order and the Question of Girls

Mica Nava

2 Femininity and Adolescence

Barbara Hudson

3 Groping Towards Sexism: boys' sex talk

Julian Wood

4 Drawing the Line

Mica Nava

5 Family Fortunes

Adrian Chappell

6 Dance and Social Fantasy

Angela McRobbie

7 Some Day My Prince Will Come

Valerie Walkerdine

8 Alice in the Consumer Wonderland

Erica Carter

Bibliography

Index 


\section{Acknowledgements}

Many people have contributed directly and indirectly to the ideas expressed in this book. We would particularly like to thank the following for their interest, support and constructive criticism: Lucy Bland; Peter Chalk; Hanna Chalmers; Martin Chalmers; Phil Cohen; Simon Frith; Phil Jones; Matthew Jones; Steven Kennedy; Clara Mulhern; Jake Nava; Orson Nava; Zadoc Nava; Michelle Stanworth.

ANGELA MCROBBIE

MICA NAVA 